\title{
怪骨骨幹遠位端骨折の治療経験
}

\author{
博慈会記念病院整形外科 \\ 田中裕 之・白 濱 正 博 \\ 松 藤 靖. 西 辻一成

\section{Clinical Experience in the Treatment of Distal Tibial Shaft Fractures}

by

Hiroyuki Tanaka, Masahiro Shirahama, Yasushi Matsufuji and Kazunari Nishitsuji

Department of Orthopedic surgery, Hakujikai Memorial Hospital, Tokyo

We treated 24 distal tibial shaft fractures in 19 men and 5 women with their average age being 41.8 years old and the average objective term being one year and two months, which included 15 open fractures, from Jan. ' 86 to Oct. ' 90.

We treated the following cases as a primary treatment: 2 conservative cases, 4 cases used with external fixations, 6 with Ender nails, 3 with T plates, 5 with AO plates and 4 with May plates.

Considering each case about the term of union, the degree of malunion and the operative result, we could get the following consequence. It took 12.0 weeks for the Ender nail group to union and 8.7 weeks for the plates group on an average. The valgus angulation developed more in the Ender nails group than the plates group. A better result could be found in tne plates group, in which the treatment using May plate was extremely good.

\section{はじめに}

怪骨骨幹部骨折に対しては，エンダー釘や横止め螺 子髄内釘の適応範囲は拡大されてきている。しかし怪 骨遠位 $1 / 4$ 以下の骨幹遠位端骨折ではその適応が困 難となることが多い. 今回その治療方法と成績を検討 したので報告する.

\section{対象症例ならびに結果}

1986 年 1 月から 1990 年 10 月までに当科入院加療 を行なった怪骨骨幹部骨折は 136 例 140 骨折で，その うち骨幹遠位端骨折は 24 例 24 骨折（17\%）であった。 男性 19 例, 女性 5 例, 年齢は 17 才から 66 才（平均 41.8 才）で, 経過観察期間は受傷後 4 ケ月から 3 年 5 ケ月, 平均 1 年 2 ケ月であった. 開放骨折は 15 例
（62.5\%）であった。受傷原因は交通事故が20例（83.3 \%) と高率で, 開放骨折 15 例は全てこれに含まれて いた. 次いで転倒 3 例, 労災事故 1 例であった.

初期治療方法についてみると, Gustilo-Anderson Type II 2 例, Type III a, II b 各 1 例の開放粉砕骨折 4 例に創治癒までの期間ホフマン創外固定器を用いた。 抜去後 1 例はギプス固定, 他の 3 例はエンダー釘, T プレートと骨移植, $\mathrm{AO}$ プレートと骨移植の追加処置 を行ない骨癒合を得た. 軟部組織損傷の程度の大きな Type III 初回処置としてプレートを用いた症例はな かった. 又, Type III c の開放骨折例はなかった（表 1 ).

最終治療法別に骨癒合時期, 距腿関節の変形治癒を レントゲン上で検討し, 成績については飯田 ${ }^{3)}$ の予後 判定基準に準じ, 優 : 全治, 良 : 軽度の ROM 制限 
表 1 初期治療方法

\begin{tabular}{c|c|c|c|c|c|c}
\hline \hline \multirow{2}{*}{ 初期治療方法 } & \multirow{2}{*}{ 皮下 } & \multicolumn{4}{|c|}{ 開放骨折 (G-A分類) } & \multirow{2}{*}{ 計 } \\
\cline { 3 - 6 } & & $\mathrm{I}$ & $\mathrm{II}$ & $\mathrm{II} \mathrm{a}$ & II b & \\
\hline 保 存 的 & 0 & 1 & 0 & 0 & 1 & 2 \\
\hline 創 外 固 定 & 0 & 0 & 2 & 1 & 1 & 4 \\
\hline Ender 釘 & 3 & 0 & 1 & 0 & 2 & 6 \\
\hline T plate & 1 & 1 & 1 & 0 & 0 & 3 \\
\hline AO plate & 2 & 1 & 2 & 0 & 0 & 5 \\
\hline May plate & 3 & 0 & 1 & 0 & 0 & 4 \\
\hline 計 & 9 & 3 & 7 & 1 & 4 & 24 例 \\
\hline
\end{tabular}

表 2 治療別成績

\begin{tabular}{|c|c|c|c|c|c|c|}
\hline \multirow{2}{*}{ 治 療 法 } & \multirow{2}{*}{$\begin{array}{c}\text { 症例数 } \\
\text { (例) }\end{array}$} & \multirow{2}{*}{$\begin{array}{l}\text { 平均骨癒合 } \\
\text { 時期（週） }\end{array}$} & \multirow{2}{*}{$\begin{array}{c}\text { 平均変形治癒 } \\
\text { (距腿関節) }\end{array}$} & \multicolumn{2}{|c|}{ 成 } & \multirow{2}{*}{$\begin{array}{l}\text { 績 } \\
\text { 可 }\end{array}$} \\
\hline & & & & 優 & 良 & \\
\hline 保 存 例 & 3 & 8.3 & $5^{\circ}$ 外反 & 1 & 1 & 1 \\
\hline Ender 釘 & 7 & 12.0 & $5.7^{\circ}$ 外反 & 1 & 2 & 4 \\
\hline $\mathrm{T}$ plate & 4 & 8.5 & $2.5^{\circ}$ 外反 & 2 & 1 & 1 \\
\hline AO plate & 6 & 8.7 & $0^{\circ}$ & 1 & 5 & 0 \\
\hline May plate & 4 & 9.0 & $0^{\circ}$ & 2 & 2 & 0 \\
\hline
\end{tabular}
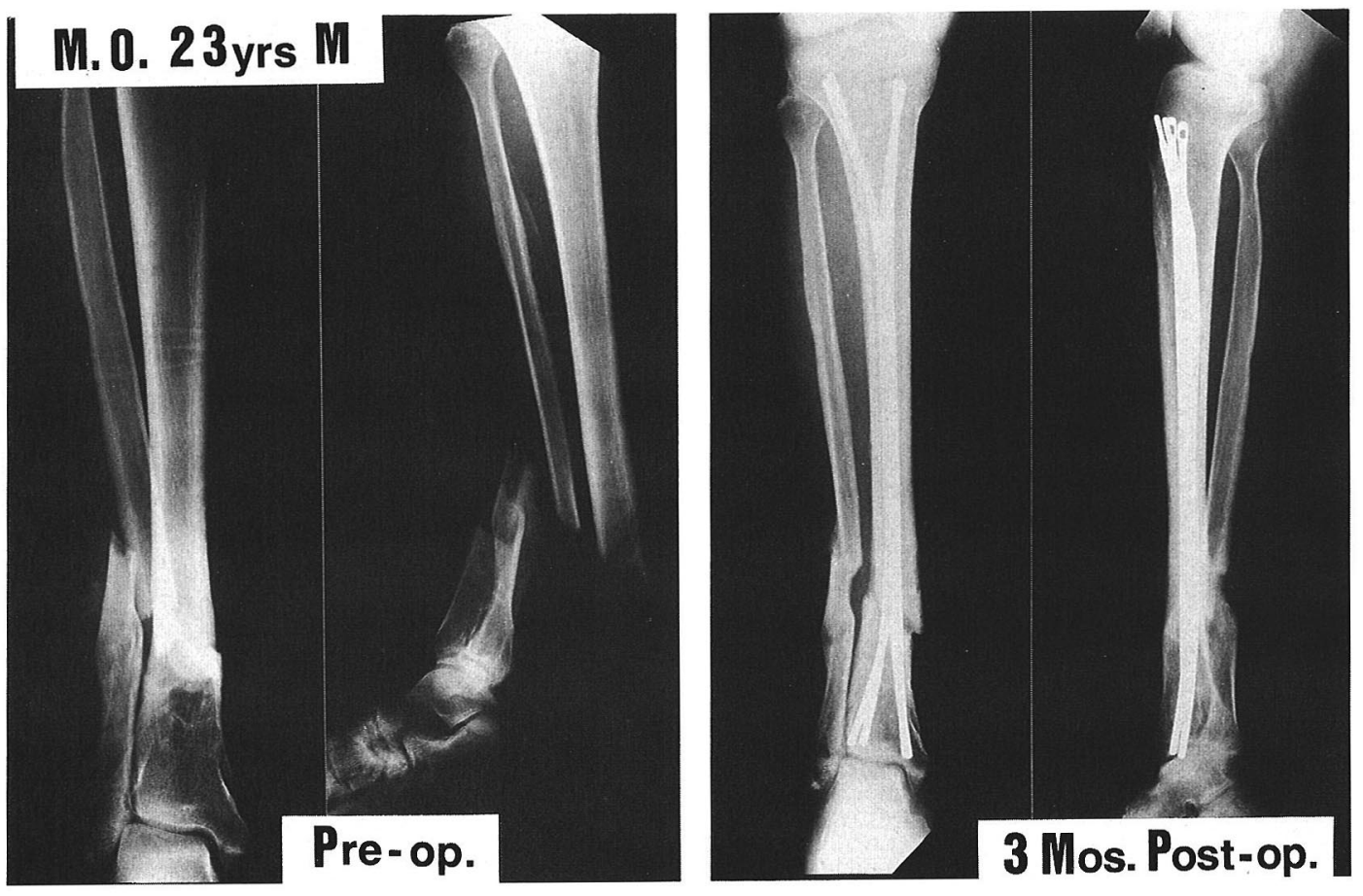

図 1 症例 1 

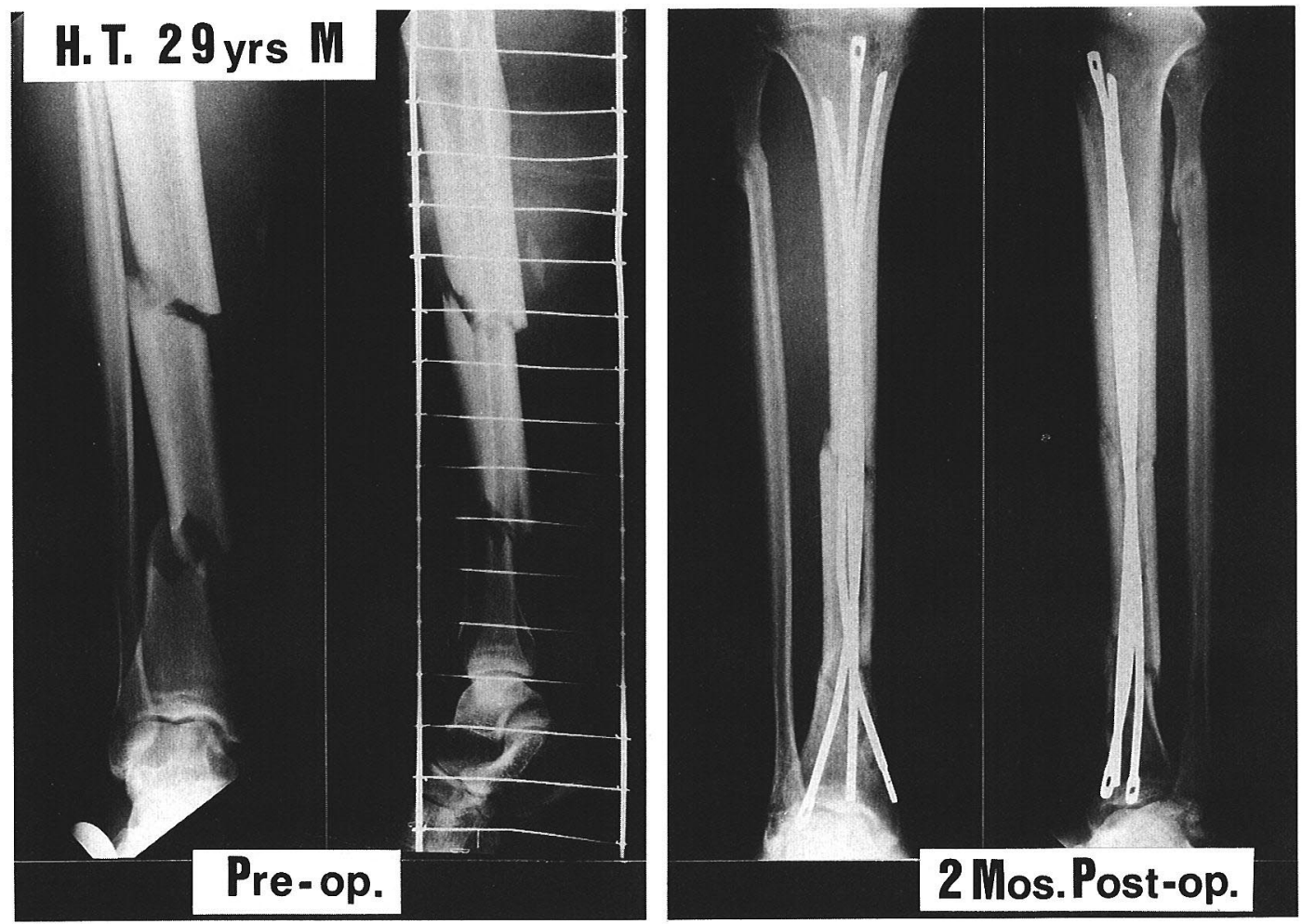

図2

症例 2

あるも $\mathrm{ADL}$ 上殆ど支障なし，可：中等度以上の ROM 制限あり ADLにも支障を感ずる，不可：未だ骨癒合 せぬもの, と 4 段階で判定した, 骨瘉合時期は, プレー 卜群ではいずれも平均術後 8.5 9.0 週（6－12 週） で骨癒合が得られたのに対し，エンダー釘群では平均 12.0 週（8〜16 週）を要していた。骨瘉合後の距腿 関節の内外反変形をみると, プレート群では Tプレー トを用いた 1 例に $10^{\circ}$ 外反をみたのみであったが，工 ンダー釘群では $15^{\circ}$ 外反 2 例と $10^{\circ}$ 外反 1 例の計 3 例 に外反変形が生じていた，内反変形を生じた症例はな かった．成績をみるとエンダー釗群よりプレート群の 方が秀れており，特にメイプレートを用いた症例で良 好な成績が得られた（表 2 ）。

\section{症}

例

症例 $1: 23$ 才, 男性.

車で電柱に衝突受傷. Gustio Type III b の開放骨 折で直ちに創洗净, デブリトマン, 一次創閉鎖し, 受
傷後 4 週でエンダー釷による骨接合術を行なった。術 後 5 週より PTB 装具装着にて部分荷重を開始. 術後 12 週より全荷重とした. 術後 1 年で抜釘し, 最終診 察時に疼痛の訴えはなかったが，足関節背屈 $0^{\circ}$, 底 屈 $30^{\circ}$ と可動域制限が認められ治療判定では可であっ た. 又, 術直後よりレントゲン上 $15^{\circ}$ の外反変形を生 じていた（図 1 ).

\section{症例 $2: 29$ 才, 男性.}

車で電柱に衝突受傷. Type IIの開放創に対し直ち に創洗浄，デブリトマン, 一次創閉鎖. 受傷後 3 週で, 怪骨内外顆部に挫創があったためC法にてエンダー釘 による骨接合術を行なった。術後 6 週より PTB 装具 装着にて部分荷重, 10 週より全荷重とした。最終診 察時レントゲン上では距腿関節に $10^{\circ}$ の外反変形を認 め, ROM 制限が軽度みられたが， $\mathrm{ADL}$ 上特に問題 なく，成績は良であった（図 2 ）。

症例 $3: 51$ 才, 男性.

オートバイ走行中車と衝突受傷. 直ちに鋼線牽引施 


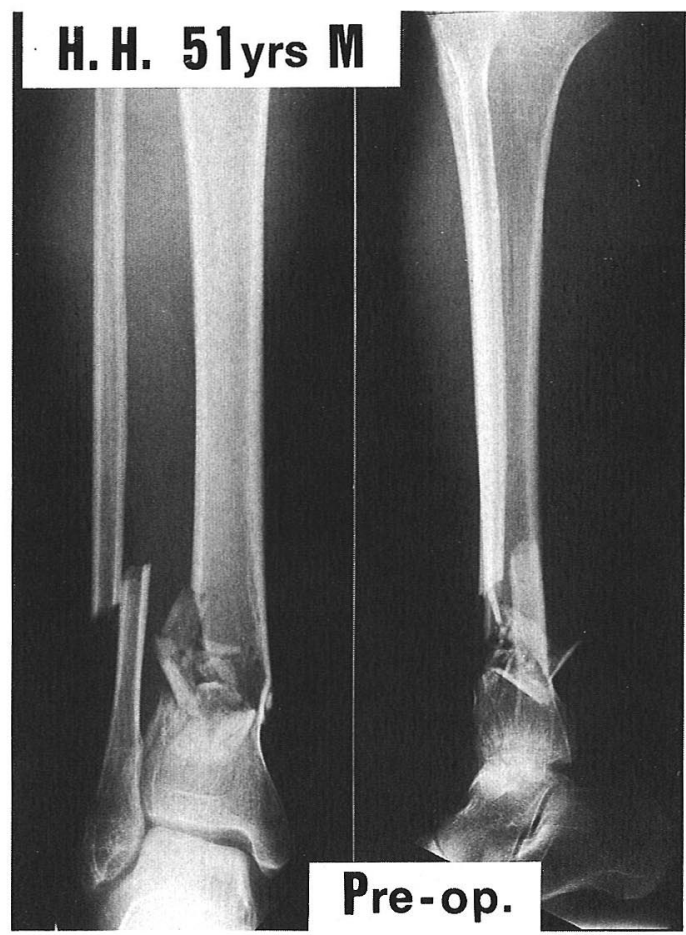

図 3

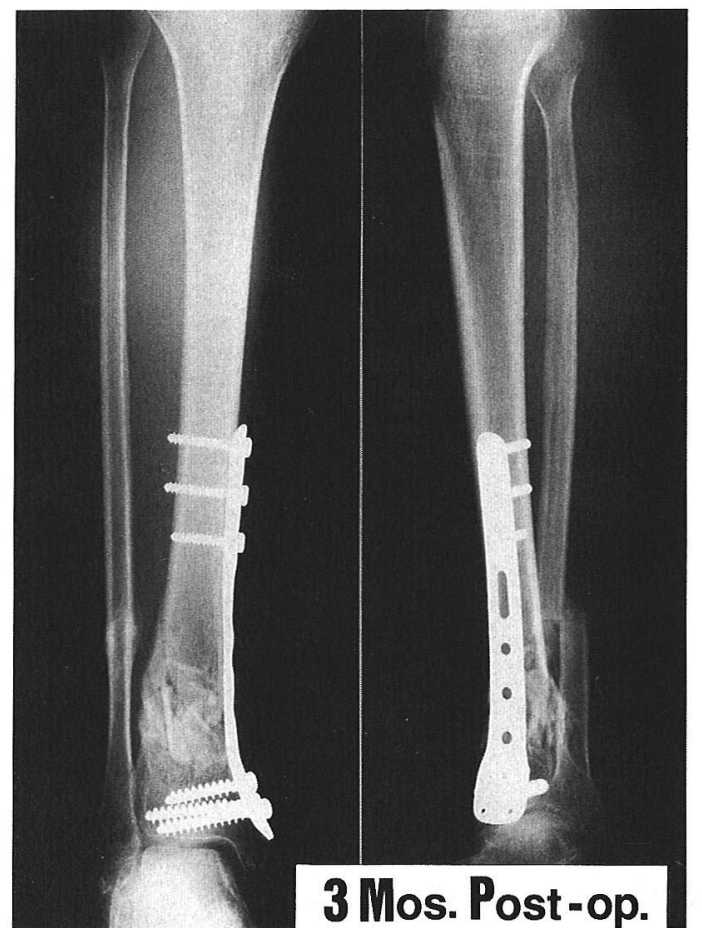

症例 3
行， 1 週後にメイプレートによる骨接合術に骨移植術 を併用した。術後 6 週までギプス固定を行ないその後 ROM 訓練, 8 週より部分荷重, 12 週より全荷重と した.レントゲン上距腿関節面の変形治癒もなく, 軽 度の足関節可動域制限を残すのみで, 成績は良であっ た (図 3 ).

症例 $4: 39$ 才, 男性.

オートバイ走行中車と衝突受傷. Type II の開放創 は洗浄後一次創閉鎖, 創治療を待ち受傷後 3 週でメイ プレートによる骨接合術を行なった。術後 8 週より PTB 装具にて部分荷重, 12 週より全荷重. レントゲ ン上変形なく軽度の足関節可動域制限を残すのみで成 績は良であった（図 4 ）。

\section{考察}

髄腔拡大部でも怪骨中下 $1 / 3$ の骨折では横止め螺 子髄内釘が適応となるが，下 $1 / 4$ 以下の骨折では横 止め螺子が骨折線に接近したり入ってしまったりする 為に適応となりにくい. 後藤らは怪骨骨幹遠位端骨折
に対してもエンダー釬が有用であると述べているが2), 我々のエンダー釗を用いた症例では外反変形を生じた ものが多くみられた。これらの変形は術直後より生じ ており，術前の正確な整複，術中エンダー釘挿入の際 の慎重な操作と整複位の保持が重要であると考えられ る、エンダー釘のこの骨折部位での整複，固定能力は 決して高くないと思われるが，軟部組織損傷の高度な 症例ではエンダー釘も有用と考える。我々は怪骨遠位 端部骨折に対しプレートを多く使用してきた. AO プ レートでは，距腿関節から骨折部までの距離，いわゆ る effective length が短い症例に対しては固定力に 問題があると考え，Tプレートや特に最近ではメイプ レートを用い骨折遠位部には海綿骨螺子を使用して良 好な固定性を得ている，メイプレートは怪骨遠位部に 解剖学的に適合する形状となっており, 正確な解剖学 的整複と強固な固定が得られ，特に距腿関節から近い 部位の骨折や粉砕骨折にも有用であると思われる4). 

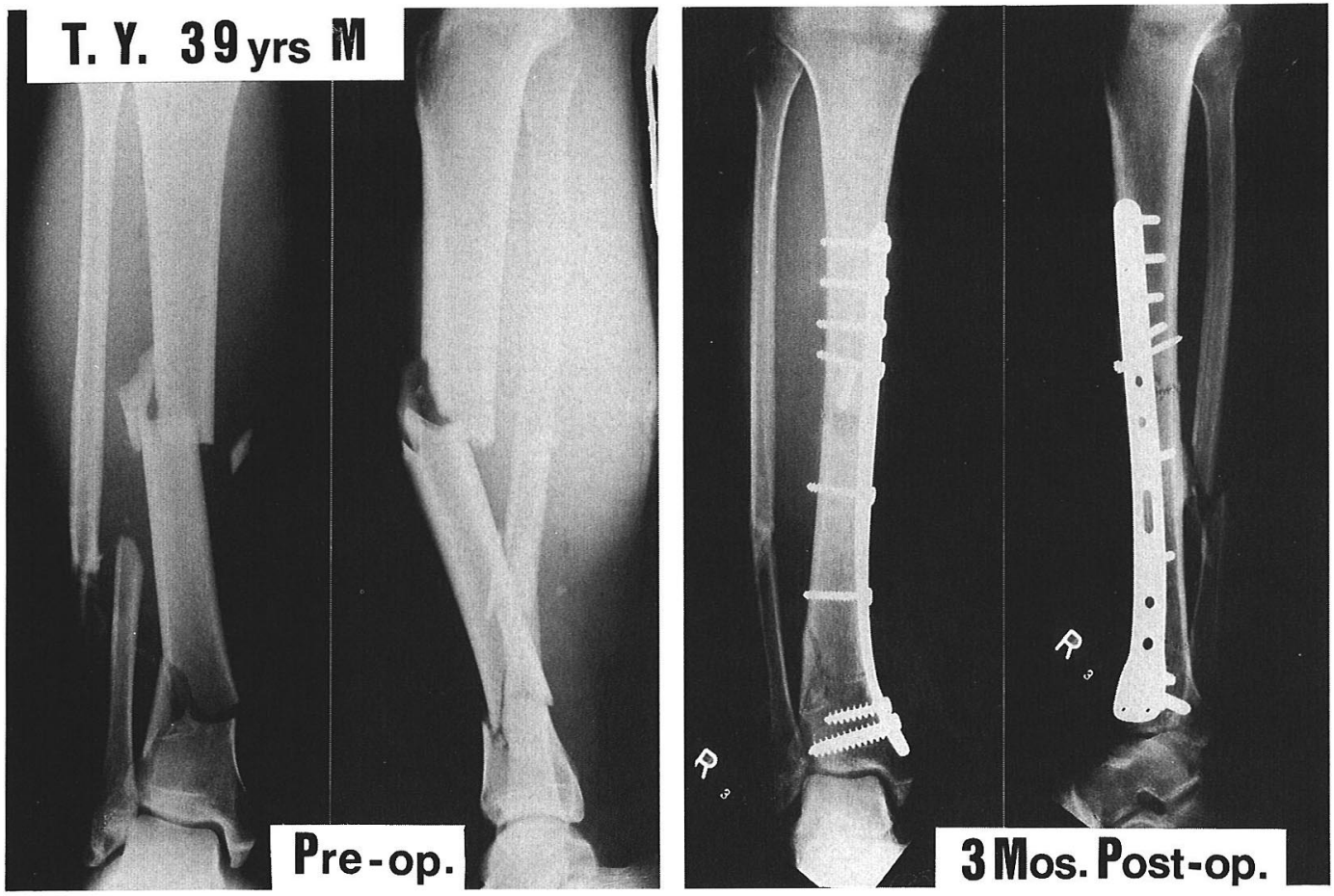

図 4 症例 4

ま と め

(1) 1986 年 1 月から 1990 年 10 月までの怪骨骨幹遠 位端骨折 24 例を検討した。

(2)骨癒合時期はエンダー釷群よりプレート群の方が 早期であった。

(3)距腿関節の変形治癒はエンダー釘を用いたものに 多くみられた。

(4)術後成績はエンダー釷群よりプレート群の方が良 好で特にメイプレートを用いたものが秀れていた。
参 考 文 献

1）青柳孝一：長管骨骨幹部骨折に対する内固定の工夫, 骨折, $11: 397-403,1989$.

2）後藤武史，他：エンダー釘による怪骨骨幹遠位端骨折 の治療経験, 整形外科と災害外科, $38: 1289-1292$.

3）飯田鴎二, 他: 下腿骨骨幹部骨折の治療, 中部整災誌, $23: 598-602$.

4) St.Thai $\beta$, V.Synatschke und E.May.: Spezialplatte zur Versorgung distaler Tibiafrakturen, chir. praxis $24: 265-273,1978$. 